\title{
Interim Sacrifice
}

National Cancer Institute

\section{Source}

National Cancer Institute. Interim Sacrifice. NCI Thesaurus. Code C90436.

An indication that the study subject was euthanized during a predetermined time. 